\title{
Two Decades of Murray-Darling Water Management: A River of Funding, a Trickle of Achievement
}

\author{
Lisa Yu-Ting Lee and Tihomir Ancev ${ }^{1}$
}

\begin{abstract}
The paper appraises the myriad of Murray-Darling Basin-related policies since the early 1990s. It contends that significant environmental improvements could have been achieved at substantially lower cost had decisive action been taken earlier. If the total expenditures in the last two decades had been put solely towards water entitlement buy-backs, an amount of water several times that necessary to significantly improve the health of the Basin would have been acquired.
\end{abstract}

\section{Introduction}

The majority of all water use in Australia is consumed in the Murray-Darling, with almost 90 per cent of the system's water diverted for extractive uses (CRCIF 2005). In recognition of inefficient water allocation among extractive and non-extractive uses, ${ }^{2}$ numerous resource policies have been implemented since the signing of the 1992 Murray-Darling Basin Agreement and the 1994 Council of Australian Governments (COAG) Water Reform. It was envisaged that these agreements would provide a coordinated approach of the concerned jurisdictions to restore the Murray-Darling system to good environmental health. Correspondingly, this period saw substantial public funds injected into natural resource management, and the advent of market-based instruments (MBIs), including cap-and-trade schemes (for example, water trade) and pricing schemes (for example, cost recovery). This policy direction was in line with the abundance of literature that advocates MBIs as the conduit to cost effectiveness, and is becoming increasingly favoured over traditional regulatory controls (Bjornlund 2003).

If judged by the media coverage of water management policies and the amount of public investment poured into various programs and initiatives, the public might justifiably have a 'feel-good' perception that some progress has been made.

\footnotetext{
1 The Centre for Applied Economic Research, University of New South Wales; the Department of Agricultural and Resource Economics, University of Sydney. Correspondence: lisa.lee@unsw.edu.au This work was funded by the Commonwealth Environment Research Facilities program. The authors would like to thank Kevin Fox, Quentin Grafton, Jeff Bennett, William Coleman and an anonymous referee for their helpful suggestions and feedback.

2 'Extractive use' refers to water for human use, and 'non-extractive use' refers to water left in-river for environmental functioning.
} 
However, evidence of tangible on-ground achievements in terms of actual environmental outcomes is sparse. There is limited empirical evidence of real improvements; in fact a 'report card' produced by the Cooperative Research Centre for Freshwater Ecology (2003) has shown a marked deterioration relative to 1994 conditions. The Living Murray Initiative and the government buy-back of water entitlements have received attention, particularly the recent purchase of properties such as Toorale for the purpose of procuring their water entitlements, which some have labelled a waste of money (Ferguson 2008). But the progress of other prominent, yet less-publicised, natural-resource management initiatives have been less assessed. The list of these programs includes, but is not limited to, the Environmental Works and Measures Program, the Basin Salinity Management Strategy, and the Australian Water Fund projects. Given the limited coverage and assessment of the various programs directed towards improved water management, it is difficult to discern the state of affairs in the Murray-Darling and to scrutinise successes and weaknesses in current policies.

The general perception is that progress in the Basin is somewhat disappointing, despite almost two decades of concerted management. This paper attempts to take stock of the achievements and progress of natural-resource policies in the Basin, and the reasons contributing to the lack thereof. This involves an overview of the evolution of public policy in water management in Australia, and an investigation into the range of government initiatives to clarify the relation between achievements and funding streams.

The overall conclusion is that, in spite of the numerous agreements and initiatives, corresponding achievements have been decidedly lacklustre due to poorly informed decisions and buck-passing between the states. There remain several weaknesses in institutional arrangements as water reform has evolved, underlying which is a significant information gap at the core of the frustrated progress. Notwithstanding information barriers, the most straightforward solution - to buy back entitlements - has also been resisted. It is the contention of the authors that, by having put off this difficult but seemingly necessary action, the social cost has become even greater than if the problem had been confronted sooner. Stronger action may have resolved water-resources issues at a fraction of the expense, had decisions been based on transparent, cost-benefit criteria unbiased by political motivations.

\section{A Brief History of Water Management in the Murray-Darling Basin}

The plight of the Murray-Darling is now a familiar story, and has been accompanied by a long string of water management policies to stem its degradation. The story also reflects the trend in favoured policy tools, from centralised regulatory directives towards reliance on market-based approaches, 
generally classed as quantity or price instruments. ${ }^{3}$ Quantity instruments, often requiring a cap, have been used as an alternative to direct regulation, commonly in the framework of a market with tradeable property rights (Rolfe and Mallawaarachchi 2007). While there has been increased use of price instruments, there seems to be a tendency to shy away from direct water pricing. For example, cost recovery for water was only ever limited to operational costs, and does not capture environmental costs of extraction. ${ }^{4}$ So price instruments come commonly in the form of auction-style tenders, grants and rebates (Rolfe and Mallawaarachchi 2007). While subsidies have largely fallen out of favour, we appear to have come full circle, with the most recent policy, the National Plan for Water Security, embracing the use of direct subsidies to 'modernise irrigation'.

Inter-governmental arrangements have evolved from the early 1900s, beginning with the signing of the River Murray Waters Agreement in 1915, which focused on resource sharing between the States. Various amendments to the Agreement made over the 70 years of its operation were only minor changes relating to the construction of dams and weirs. The need for balance between environmental and extractive demands came to light as Australia's water economy moved into its mature phase, symbolised by the signing of the Murray-Darling Basin Agreement in 1992 (Quiggin 2001). The 1994 COAG Water Reform (Water Reform) marked the initial shift in natural-resource management towards market-based solutions, and was integral to the Federal Government's National Competition Policy for competitive neutrality in key industries. The Cap was also introduced in 1995, alongside the water reform to enable transferable property rights for water. ${ }^{5}$ The water-reform process was tied in with National Competition Payments to motivate its implementation, although this financial incentive had varying degrees of success in promoting the full water-reform agenda. The Payments represented the first of a string of Federal funding towards environmental management in the years to follow. It can be regarded as a precursor to the weak correlation between government spending and outcome in natural-resource policies.

Problems contributing to stagnating progress since the 1994 Water Reform related to institutional factors in water-sharing arrangements, pertaining to the specification of property rights for extractive and non-extractive uses which compromised the security of water entitlements. In 2004, the National Water Initiative was introduced to overcome these sticking points, resulting in an

\footnotetext{
${ }^{3}$ Market-based instruments use market-like processes, represented by a network of regulatory and incentive structures, which coordinate individual preferences and allow greater flexibility for participants to undertake mitigation actions suited to individual circumstances (Rolfe and Mallawaarachchi 2007).

${ }^{4}$ One justification for this is that higher usage charges may erode market prices if environmental costs are fully accounted for (Grafton and Hussey 2007).

5 The Cap is a limit placed on the level of water diversions in the Basin, relative to 1994 baseline conditions.
} 
agreed public-private cost-sharing arrangement if environmental flows were to be increased (Freebairn 2005). It was also agreed that priority would be given to the provision of water for the environment ahead of extractive use, representing a fundamental shift from the view that water management is designed to coordinate increased water use (Connell and Grafton 2008). Discussions on missing property rights over externalities associated with return flows also took place, in particular on the impact of increased water-use efficiency on downstream users; and the implications that water trade between hydrological systems has for water quantity and quality. Following from this was the introduction of 'exchange rates', in part to try and capture transmission gains or losses for interregional trading. ${ }^{6}$ This was in spite of there being significant knowledge gaps in understanding hydrological systems, which raises concern over the prudence of using those exchange rates. Another example where a rush for action overshadowed the need for robust information and evaluation is the Landcare program. Government failure in this instance led to excessive and poorly distributed public expenditure on small on-ground works (Pannell 2008).

Other prominent programs developed during this period include the Living Murray Initiative and Basin Salinity Management Strategy. The Living Murray began in 2002, aiming to deliver environmental improvements through the Water Recovery and Environmental Works and Measures Programs. The 2001 Basin Salinity Management Strategy focused on salinity-related problems in the Basin, and is linked to the National Action Plan for Salinity and Water Quality. The relevant governments also agreed to build salt-interception schemes under the Joint Works Program to achieve salinity reduction at Morgan, South Australia (which is at the mouth of the Basin). These initiatives represent substantial funding to deliver environmental improvements at target sites, with increasing reliance on market mechanisms, although still conspicuously avoiding direct buy-back. This shift away from 'command-and-control' policies reflects greater public acceptance of economic instruments in environmental management.

The most recent policy development was in January 2007, when the Federal Government announced the National Plan for Water Security - since renamed 'Water for the Future' by the succeeding government in 2008. The strategy of this Plan was in accordance with the objectives outlined in the National Water Initiative; specifically; to address over-allocation, to modernise irrigation, and to create a transparent water-management system. By this stage, market-based instruments have become fairly mainstream, with one-third of the funds to be

\footnotetext{
${ }^{6}$ Exchange rates are a conversion rate for water traded between hydrological systems, since the security of the entitlement is not perfectly preserved because of transmission losses. For example, 1 unit upstream can be traded downstream at a conversion rate of 0.9. Some interstate trades also occur under a system of 'tagging', where water traded between states continues to be tagged according to its point of origin and continue to be managed the same way (Brennan 2007). However, this is so complex it appears only one trade has occurred under the tagging system (personal communication).
} 
directed at buying back entitlements. Water information has also become a priority area, and for the first time irrigators are required to disclose water-use information to public institutions. This was done in parallel with efforts to improve basin-wide hydrological modelling.

\section{The river of funding}

A large number of programs and initiatives have been implemented to manage the Murray-Darling since 1992. These programs have been accompanied by a constant stream of government funding, as well as top-ups and other funding avenues. However, much like the situation with the river basin itself, while a lot went into these policies, little seems to have come out. In this section, details of high-profile Basin-related programs and investments are provided, with the aim to show that overall achievements do not reflect the generous funding. All along, the redistribution of extractive water towards ecological uses has remained a vexing point; the justification being, the cost of water reallocation should be justified by the environmental benefit it would generate. However, there is insufficient information to evaluate trade-offs between environmental benefits and economic losses (Grafton and Hussey 2007). For all the worry, expenditure on the agreements and initiatives has likely outstripped the cost of redistributing water towards environmental use. Earlier decisive action with a good science-based approach, removed from politics and workarounds, may have avoided the excesses.

A summary of relevant intergovernmental and Commonwealth programs, and their funding contributions, is provided in Table 1.

\section{Water Reform and National Competition Policy}

The development of water markets has been highly publicised, having been regarded as the 'holy grail' for water-allocation problems. While water markets have been established in most catchments, water trading has remained rather limited. In the past, trade has been confined to high-security licences in middle and lower reaches of the River Murray (Connell 2007). Even with the rules relaxed, trade in permanent water entitlements was less than 1 per cent of diversions in 2001-02, with less than $1 \%$ of all trade occurring inter-regionally (Heaney et al. 2004). ${ }^{7}$ In 2005-06, permanent trade remained below 1 per cent of the entitlements, and temporary trade under 10 per cent of annual allocations. Of the total temporary trade, 4lGL (5 per cent) were sold interstate (MDBC 2007b). This is explained by the existence of several barriers to trade, including a 4 per cent limit on sales of entitlements outside of irrigation districts, and exit fees that will remain until 2016 (Connell and Grafton 2008). Taxation issues

\footnotetext{
${ }^{7}$ Permanent water trade refers to permanently selling the ownership of the entitlement to another party, while temporary water trade refers to selling the right to use the seasonal water allocated to the entitlement, but retaining the ownership of the entitlement.
} 
present further institutional constraint on permanent trading; temporary purchases are fully tax deductible in the year of purchase whereas permanent purchases can be subject to capital gains tax (Bjornlund 2003).

Table 1: Summary of government initiatives and funding arrangements

\begin{tabular}{|c|c|c|}
\hline Programs for the Murray-Darling Basin & Funding (\$m) & Timeframe \\
\hline National Competition Policy (inc. Water Reform) & 3900 & $1997-2004$ \\
\hline $\begin{array}{l}\text { The Living Murray First Step (TLM) } \\
\text { - Water Recovery } \\
\text { - Environmental Works and Measures Program }\end{array}$ & $\begin{array}{l}500 \\
150\end{array}$ & $\begin{array}{l}2004-09 \\
2003-11\end{array}$ \\
\hline Commonwealth Supplementary Contribution to TLM & 500 & $2006-11$ \\
\hline $\begin{array}{l}\text { National Water Initiative } \\
\text { - Australian Water Fund }\end{array}$ & 2000 & $2004-10$ \\
\hline $\begin{array}{l}\text { Water for the Future (formerly National Plan for Water } \\
\text { Security) }\end{array}$ & 12900 & $2007-17$ \\
\hline Joint Works Program (Basin Salinity Management Strategy) & 60 & 2001-present \\
\hline Natural Heritage Trust and National Action Plan & $\begin{array}{l}400 / y r \\
\text { (tot. } \approx 3000 \text { ) }\end{array}$ & $2001-08$ \\
\hline Caring for our Country (Natural Heritage Trust 3) & 2250 & $2008-11$ \\
\hline Retiring properties in Queensland and NSW ${ }^{1}$ & 50 & 2008 \\
\hline TOTAL & 25310 & \\
\hline (without National Competition Policy) & (21 410) & \\
\hline
\end{tabular}

1: This new money was sourced to purchase Toorale Station.

Note: State-based arrangements are not included.

There have also been several unexpected consequences, including the fallout in increased water use as 'sleeper' and 'dozer' licences are activated in trade, stranded assets, and reduced return flows as irrigation efficiency increases. In addition, the push for greater water trading in the National Water Initiative has encountered problems of variability of supply and hydrology between catchments, resulting from gaps in biophysical and hydrological knowledge (Connell 2007). Furthermore, there is a general apprehension towards the water market, drawing from concerns pertaining to community decline, threat of foreign ownership, and a perceived loss of subsidies (Randall 1981). Concern over the impact on property values of selling entitlements and policy uncertainty over future allocations are other factors limiting permanent water trade (Bjornlund 2003). To circumvent the thin-market problem, and in an effort to discover efficient prices, there has been a move towards tenders for buying back entitlements. However, there remains resistance from rural communities to recent government purchases, even though there is evidence of growing support where the buy-back is perceived to generate justifiable benefits.

\section{The Living Murray First Step}

Part of the Living Murray agreement was the First Step program, developed in 2003, which identifies six 'ecological assets' in the Basin to be protected. The implementation of the First Step was endorsed as part of the 2004 National Water Initiative under the Intergovernmental Agreement, in which contracting 
governments agreed to commit $\$ 500$ million over five years for the recovery of (on average) 500GL of water per year for the environment - known as "new environmental water' or 'new e-water'. ${ }^{8}$ This sum was allocated towards the Water Recovery program for a set of approved market-based variants of buy-backs and infrastructure projects.

Overall, water recovery lagged, and it was not until February 2008 that there were enough projects approved to potentially recover the full 500GL. ${ }^{9}$ April 2008 marked the historical first 'water recovery' event, with 133GL of environmental water entitlements secured in Victoria and South Australia. While the first water recovery is a significant milestone of the Living Murray, most projects are still under development; 367GL still need to be recovered at the rate of at least 1500 megalitres (ML) per day to achieve the full 500GL by mid 2009. ${ }^{10}$ Also, no physical environmental water will be released except in wet years (MDBC 2008). This has obvious implications for the sustainability of water sharing under the expected long-term climate change, in addition to the inconsistency with National Water Initiative commitments to prioritise ecological preservation over irrigation interests.

Complementing the Living Murray First Step, the Environmental Works and Measures Program was created in 2003, with a funding of $\$ 150$ million over eight-years for capital works and improvements in infrastructure targeting the six ecological assets, such as upgrading weirs and fish ways. No evaluations of the effectiveness of the program are yet available; however, a task force has been established for this purpose.

In addition to the First Step, there are also substantial efforts being made towards environmental water recovery at State level. For example, the NSW Government allocated \$13.4 million towards its Wetland Recovery Plan in 2005, a sum that was matched by the Commonwealth via the Australia Water Fund. The objective is to permanently recover water for ecologically significant wetlands through infrastructure projects and buying back entitlements, which so far has acquired 6.5GL in the Gwydir and Macquarie. ${ }^{11}$ There is also the NSW Riverbank Fund introduced in 2006, which allocated \$105 million towards buying back water for environmental purposes. Other Riverbank projects were also supplemented with $\$ 72$ million from the Australian Water Fund. In July 2007, 15GL of environmental water was purchased for the Gwydir, Macquarie,

\footnotetext{
${ }^{8}$ Water recovery refers to the process of recapturing water from other uses and directing it towards environmental purposes. In effect, the environment has entitlement over this water. The 500GL to be recovered is 'new' in the sense that the States will contribute new funds to recover this water, on top of pre-existing commitments.

${ }_{9} \mathrm{lGL}=1000 \mathrm{ML} ; 1 \mathrm{ML}=1$ million litres, which is equivalent to the volume of water in an Olympic swimming pool.

${ }^{10}$ From October 2008.

11 The Wetland Recovery appears to be unrelated to the Living Murray, and could be considered 'other new e-water'.
} 
Lachlan and Murrumbidgee rivers in NSW. Riverbank's role has since expanded to include the Market Purchase Measure as part of The Living Murray Water Recovery, to buy back 125GL via a tendering process (NSWDECC 2008). However, it is unclear how much physical environmental flows will eventuate from these entitlements.

\section{Commonwealth Supplementary Fund to the Living Murray}

In 2006 a one-off supplementary funding of $\$ 500$ million was made to the Murray-Darling Basin Commission by the Commonwealth, as a top-up to the $\$ 500$ million for the First Step Agreement. The supplementary contribution is to be spent over five years from 2006. Of this, \$200 million was allocated for Water Recovery alone, bringing its total to $\$ 700$ million over five years. Of the remaining supplementary fund, \$100 million was flagged for infrastructure projects under the Environmental Works and Measures Program, totalling \$250 million. The rest of the supplementary funding was to hasten other programs, including the Basin Salinity Management Strategy, although it is uncertain how this was distributed (MDBMC 2006).

As mentioned, 133GL of water entitlements have been 'recovered' as at mid 2008. If the full 500GL is recovered, the average cost reduces to $\$ 1,400 / \mathrm{ML}$. Based on 2006 market prices, this is more than three times greater than permanent water rights of $\$ 400 / \mathrm{ML}$ in the Murray Irrigation Limited (Quiggin 2006). Had the water-recovery funding been put entirely towards entitlement buy-back at this price, this would have resulted in a total of 1750GL of new e-water - three times greater than the Intergovernmental Agreement target of 500GL, and sufficient for moderate improvements in the health of the Murray-Darling.

\section{The Cap}

The implementation of the Cap has been delayed in three of the five contracting States; although most valleys are within long-term targets (MDBC 2007a). Each State is required to have water-sharing arrangements as part of its obligations under the National Water Initiative. For example, in New South Wales this takes the form of Water Sharing Plans, in which environmental flows beyond Cap provisos have apparently been stipulated (NSWDNR 2008). The Basin Plan has requirements for a new sustainable Cap to be set, incorporating the inter-linkages between surface and groundwater systems. However, how this new Cap will be reconciled with the existing commitments in current water-sharing plans is yet to be resolved (Connell and Grafton 2008).

Environmental flows derived from the Cap and investments outside of the Intergovernmental Agreement can be considered 'old e- water' or 'other new e-water'. Since 1999, combined old and other new e-water releases from NSW and Victoria total around 770GL, made up of one major release of 500GL in 2006, for the Barmah-Millewa site, and a series of smaller flow events (NSWDNR 2008). 
Considering that 95 per cent of bulk water off-take occurs in NSW and Victoria (MDBC 2006), these releases account for almost all environmental flows to the Basin. ${ }^{12}$ This averages $86 \mathrm{GL} / \mathrm{yr}$ over the last nine years (less if the 500GL release in 2006 is excluded). Even in aggregate with the 133GL of new e-water, average environmental water provisions remain well below the 500GL/year target. This is unlikely to have preserved environmental sustainability as per the stated purpose of the Cap.

The impact of the Cap is more difficult to discern in unregulated systems. ${ }^{13}$ The available means of monitoring extractions often involve just one gauge at the upstream and downstream end of unregulated rivers, and penalties for over-extraction are based on the three-year average flow at the downstream gauge. The lack of monitoring capacity limits the extent to which the Cap and water-sharing arrangements can be enforced. For that matter, a general lack of water information has been a persistent issue underlying the inability to manage water effectively, which, until recently, has been recognised but ignored.

\section{National Water Initiative - the Australian Water Fund}

The Australian Water Fund was set up by the Prime Minister in December 2004 for implementing actions towards National Water Initiative objectives. A commitment of $\$ 2$ billion over five years was allocated among three programs under the umbrella of the Australian Water Fund: Water Smart Australia, Raising National Water Standards, and Australian Water Fund Communities. These programs were designed to 'improve water-use efficiency' via technological or infrastructural means, and through increasing capacity for water management.

Given the nature of Australian Water Fund projects, it is difficult to gauge environmental outcomes against which to measure progress; for example, projects which improve water accounting and develop water markets funded via Raising National Water Standards. Projects under Water Smart Australia and Community Water Grants, such as wetland management or water-recycling systems, may deliver more tangible environmental and water-efficiency improvements. While the projects appear to follow a vague mantra of 'increasing water efficiency', they may not meet the efficiency criterion. For example, rainwater tanks provide a 'feel-good' factor, but they do not represent an efficient solution to augmenting supply; households can be better off under scarcity pricing for water, which better coordinates demand and supply and removes the need for water restrictions (Grafton and Ward 2007). Without clear targets or reliable means to evaluate a project's effectiveness, there is no reliable indicator of its success. This

\footnotetext{
12 'Bulk water off-take' refers to diversion from the river greater than 5GL/yr, which supplies a multitude of users via delivery channels (MDBC 2006).

13 'Unregulated' catchments refer to river systems without an upstream head dam to 'regulate' downstream water releases.
} 
undermines the capacity for future investment decisions, which can become an exercise in distributing funds rather than achieving desired outcomes.

\section{Water for the Future (formerly National Plan for Water Security)}

The National Plan for Water Security added a further $\$ 10$ billion to the mix, which increased to $\$ 12.9$ billion when the Plan was re-branded as Water for the Future in early 2008. At the March 2008 COAG meeting, a Memorandum of Understanding for the Murray-Darling Basin Reform was agreed to by all States, including Victoria which initially opposed the reform. This took $\$ 1$ billion in sweeteners to the Victorian government, which leaves $\$ 1.9$ billion as the net increase to Water for the Future. ${ }^{14}$ The ensuing Basin Plan has an important feature whereby a final decision-maker - a Commonwealth Minister — settles disputes between the States. This is envisaged to reduce the politicised nature of the Murray-Darling Basin Commission, which has overshadowed decision-making processes (Blackmore 2002; Scanlon 2006). The Water for the Future package has various novel - though sometimes conflicting - objectives.

Of the $\$ 3$ billion earmarked for the Addressing Over-Allocation component, \$50 million was offered in a first round of buy-backs from February-May 2008. The first round acquired 35GL of 'other new e-water', at an average cost of $\$ 1400 / \mathrm{ML}$; according to different sources only $\$ 37$ million had been spent to acquire 22GL, in which case the average cost is $\$ 1700 / \mathrm{ML}$ (Wong 2008; Bardon 2008). It would appear that the value of entitlements has been inflated in the course of government buy-backs; the price is likely to increase as more substantial purchases are made (Connell and Grafton 2008).

The \$6 billion Modernising Irrigation component, largely in the form of subsidies for water-efficient irrigation technologies, can further increase the cost of water recovery as it is in direct conflict with the objective to retire inefficient irrigation areas. The financial assistance for water-efficient technologies allows less-efficient irrigators to remain in the industry, and to use the water savings to expand irrigated production (Ancev and Vervoort 2007). In this sense, the value of such properties becomes inflated and unnecessarily increases the cost of buy-backs.

The smaller, but significant, element of the plan is Improving Water Information, towards which $\$ 480$ million has been allocated. The Bureau of Meteorology has been given new powers to request water information from various parties to be used in a National Water Account. Under current arrangements, even where water metering is in place, water-extraction data is considered confidential and is not publicly disclosed (Hudson 2005, personal

\footnotetext{
14 The $\$ 1$ billion 'sweetener' is part of the old-money offered under the \$10 billion National Plan for Water Security (Milne 2008).
} 
communication). The new arrangement would mean this information is relayed to the Bureau of Meteorology, allowing for better water management through transparent monitoring of water use on a national basis. For this purpose, $\$ 620$ million of the Modernising Irrigation component has also been allocated for water metering and telemetry rollout, administered by the Department of Environment, Water, Heritage and the Arts (Vertessy 2007). ${ }^{15}$ This brings the total investment in water data to over $\$ 1$ billion over the next 10 years, signalling the emphasis now given to accurate water information.

\section{The Joint Works Program: The Basin Salinity Management Strategy}

The Joint Works program began in 2001, and is a jointly funded program to build six major salt-interception schemes as part of the Basin Salinity Management Strategy. The program is estimated to cost $\$ 60$ million, with six jointly funded schemes towards keeping salinity below $800 \mathrm{EC}$ at Morgan. ${ }^{16}$ These new schemes are in addition to seven State-owned schemes predating 1988, and in aggregate are expected to contribute 61EC of the salinity target (MDBMC 2006). In other words, the cost to reduce salinity is at least $\$ 1$ million/EC given the $\$ 60$ million investment. Despite being a pragmatic solution, salt-intervention technologies are expensive and treat only the symptom rather than the cause; that is, from non-point pollution that continues to introduce salt into the system. This is evidenced by recent experience with the Salinity and Drainage Strategy (now the Basin Salinity Management Strategy).

The Basin Salinity Management Strategy was developed in 2001, as the successor to the 1988 Salinity and Drainage Strategy. The Salinity and Drainage Strategy was a once-off agreement between the States and Commonwealth to finance activities to reduce salinity. This was initially deemed successful, as major investments made towards salt-interception schemes led to an immediate reduction in salinity throughout the 1990s. However, it soon became evident that further action was needed as salinity continued to rise, motivating the new Strategy in 2001 (Conner 2004).

The Strategy manages basin-wide salinity through end-of-valley targets and an overall downstream target at Morgan in South Australia. The States work to achieve these targets through in-valley actions, which are entered into a central Salinity Register managed by the Murray-Darling Basin Commission. The Register also captures legacy impact from previous activities and current salinity-reducing or -increasing activities, which are calculated in dollar terms using modelled cost-functions. The objective is to ensure there is net credit for each State and

\footnotetext{
15 'Telemetry' refers to the remote measurement and reporting of information.

16 Electrical conductivity (EC) is a measure of concentrated salts in the water. A high reading indicates high salt content.
} 
the Basin as a whole. Through these measures, in-valley actions are expected to offset 10EC points at Morgan, while salt-intervention schemes are expected to offset 61EC points. In 2005-06, these measures combined achieved the salinity target at Morgan (MDBMC 2006), although this success is still largely attributed to salt-interception schemes. A sustainable, long-term solution would be to change the pattern of land use to reduce the movement of salts. Targeted in-valley measures could potentially make a greater contribution; for example, Heaney et al. (2000) have shown that reforestation at sites with faster-responding, saline aquifers with porous soils can efficiently reduce salinity. Such long-term strategies will become feasible as greater hydrological information becomes available.

The main stumbling block for the Strategy (as is the case for water recovery) is the measurability of outcomes, with monitoring and evaluation identified as key areas for improvement. The reliability of entries in the Salinity Register is evaluated according to a standardised classification protocol, according to which most of the entries are of low reliability. This undermines the confidence in the progress of signatory States (MDBMC 2006). A contributing factor may be that each State uses its own hydrological models to estimate salinity impacts, each of which have strengths and weaknesses and are useful for different purposes. Following from this is a strong impetus for hydrological-economic models to be consolidated so that salinity impacts are modelled consistently, and thereby improve the transparency of investment decisions. There also remain significant information gaps in groundwater hydrological functioning. For example, IQQM models surface water and MODFLOW models groundwater, each with weak hydraulic interactions between surface and groundwater (Letcher and Jakeman 2002) — which is arguably a fundamental knowledge gap to understanding salinity. This has implications for the reliability of bioeconomic models which base cause-effect relationships on such hydrological models.

\section{Other Related Programs}

This subsection covers the following programs and activities: retiring properties in Queensland and NSW; the Natural Heritage Trust and National Action Plan for Salinity and Water Quality; and the National Competition Policy.

The considerable controversy over Federal government plans to retire properties that can provide flows to the Murray-Darling can be largely attributed to unease over the socio-economic impact of such purchases. In a recent move by the Federal government, $\$ 50$ million of new money has been flagged for the purpose of acquiring land with large water storages (ACF 2008). The first purchase was Toorale, which cost $\$ 24$ million split between the NSW and Federal government. The property held 14GL of entitlements. That is to say, it was bought at an average cost of $\$ 1700 / \mathrm{ML}$, equivalent to the cost in the first round of Addressing Over-allocation under Water for the Future. Toorale seems to 
have attracted significant media attention because it was purchased in the midst of rural discontent over the buy-backs, and was particularly contentious because of Toorale's history and the potential for benefits to be offset by irrigation expansions in Queensland (Ferguson 2008). However, a similar purchase was made in August 2008 of the Pillicawarrina cotton property in the Macquarie Marshes, under a joint venture by the Commonwealth and NSW governments through Riverbank. The land was reportedly acquired for \$10 million with 7GL of entitlements (The Land 2008); at an average cost of $\$ 1400 / \mathrm{ML}$, this is similar to the cost of Toorale. Pillicawarrina was fully operational as a cotton farm, yet its purchase had widespread support from landholders, and did not attract the same media coverage as Toorale. The main issue at stake seems to be community disgruntlement over government decisions which were perceived as being questionable and not well justified in terms of the benefits they would deliver.

Other national programs include the Natural Heritage Trust and National Action Plan for Salinity and Water Quality, which funded environmental conservation activities delivered through Regional Natural Resource Management bodies. Joint funding to these programs has averaged $\$ 400$ million/yr since its inception in 2001. In the third phase of Natural Heritage Trust from 2008, a further $\$ 2.25$ billion over five years is committed towards States' natural-resource strategies operating under the guise of Caring for our Country (DAFF 2007). Another significant source of funding was the National Competition Policy. While not directly related to natural-resource management, tranche payments were tied into the water-reform process and totalled \$3.9 billion from 1997-2004 (NCC 2005).

The projects under Natural Heritage Trust and National Action Plan were largely small-scale, and unsuccessful in some instances. With some exceptions, most of the investments promoted practices that were not adoptable at the required scale, or were invested in the wrong places (Pannell 2008). In an audit report, it was noted that there was an absence of consistently validated data and insufficient information to indicate whether the programs were meeting expectations. The audit also highlighted the need to address the transparency and accountability of funds, and problems with the quality and measurability of targets directly linked to the paucity of scientific data (ANAO 2008). The issue of transparency and measurability of outcomes is a common theme throughout most natural-resources programs, compromising the cost effectiveness of on-ground actions.

In summary, public investment into natural-resource management totalled at least $\$ 25$ billion over the last 17 years, or $\$ 21$ billion excluding the National Competition Policy. In spite of the substantial expenditure, this has not produced the envisaged restoration of over-allocated river systems. Investment decisions appear to be without strong justification; the most cost-effective solution to 
buy-back rights from irrigators has, until recently, largely been avoided (Quiggin 2008). There remains resistance from the rural community, who are unconvinced of the merits of government buy-back. Furthermore, the numerous initiatives will likely benefit from better-defined deliverables to rationalise the sums allocated and develop a way of quantifying results.

\section{Transparency, Consistency and Courage}

Overall, there has been some progress and some prudent, if somewhat ineffective, measures have been implemented. Government failure here has been in the familiar tradition of funds being hypothecated without due evaluation, perhaps as temporary fixes or on account of ulterior motives. A fundamental issue is the paucity of reliable scientific information against which to scrutinise decisions, blurring accountability and the cost-effectiveness of investments. Decisions backed by good science-based criteria and well defined trade-offs will improve transparency and help avoid politically-driven motivations (Connell and Grafton 2008). It will also justify difficult decisions that are needed to prevent environmental collapse in the Lower Murray.

Information on water use has been an area of neglect, but has gathered momentum in recent years, as reflected by the investment of $\$ 1$ billion towards improving water-data quality and metering technology. The National Water Account will be based on a comprehensive 'geofabric' — in collaboration between the Bureau of Meteorology, the CSIRO and Geosciences Australia - which will tie together all water information including hydrological flows, water use, climate, and so on (Vertessy 2007). ${ }^{17}$ The Bureau of Meteorology will also will build upon CSIRO work on the Murray-Darling Basin Sustainable Yields Assessment, commissioned in November 2006 and funded under the Australian Water Fund Raising National Water Standards Program (Vertessey 2008, personal communication). This involves building a 'supermodel' to estimate the current and future water availability, and the level of over-allocation, in all catchments within the Basin. A novel component of the model is that it makes use of existing State agency models (CSIRO 2007). This is an important move towards standardising the quality of hydrological information used in assessing land-use changes. It is logical that evaluations are based on a single, comprehensive basin-wide model which can capture whole-of-catchment effects and interdependencies consistently.

A useful extension may be to incorporate on-ground data to reflect tangible outcomes and environmental impacts. This will be possible as improved information of the system comes to hand, which should feed into overall water planning in order to maximise public benefits (Connell and Grafton 2008). For

\footnotetext{
${ }^{17}$ Individual irrigators will be required to provide monthly extraction volumes; however, their identities will remain confidential.
} 
example, the Integrated Monitoring of Environmental Flows program in NSW has been in place since 1997 to monitor the effect of environmental rules in regulated systems in the Barwon-Darling River. Integrating data from such empirical studies would help verify outcomes and provide an indicator of environmental improvement. Data from airborne electromagnetic surveying (AEM) could also be used to supplement knowledge of surface and groundwater connectivity across landscapes at high risk of salinity, and to inform strategic decisions such as reforestation.

A particular challenge to current institutional arrangements relates to water sharing between the jurisdictions. As a condition of the States agreeing to the Basin Plan, existing water-sharing plans will remain in effect until its expiry, even if sharing rules are incompatible with the sustainability principles of the National Water Initiative. This incongruence limits the capacity for effective environmental-water management across the jurisdictions, given that future shifts towards dryer climates will require that water-sharing plans be revised and be responsive to such environmental threats. Adequate revisions will likely inflict major political and economic pain on all parties (Connell and Grafton 2008). However, without the necessary changes it is likely future water security will be compromised, leading to even greater social costs.

\section{Social Cost of Inaction}

Water buy-back has long been advocated as the most efficient solution to the over-allocation problem in the Basin, but it has been left as the last resort in favour of other workarounds (Quiggin 2008). The lagging resolve meant that opportunities for acquiring low-value entitlements early on have been missed. During the current drought, prices for permanent licences have reached as high as $\$ 2000 / \mathrm{ML}$, which is a far cry from 2006 prices of $\$ 400 / \mathrm{ML}$. However, even at the likely long-term prices for permanent entitlements around $\$ 1000 / \mathrm{ML}$, $\$ 500$ million would suffice to recover 500GL - which could be achieved over five years at $\$ 100$ million/yr (Quiggin 2008). Even at the observed premium of \$1400-1700/ML in the current buy-back — indicating an endowment effect $\$ 850$ million is enough to meet Living Murray obligations. This is but a fraction of the 'Addressing Over-Allocation' component of Water for the Future.

Suppose the total expenditure on natural-resource management, of $\$ 21$ billion, had been put towards buy-backs since 1992, price unadjusted. At $\$ 1000 / \mathrm{ML}$, at least 21 000GL could have been acquired permanently. Even at $\$ 2000 / \mathrm{ML}$ a significant mark-up compared to prices only just two years ago - at least 10 500GL could have been recovered. This is far beyond the recommended 4000 GL/year required for good improvements in the health of the Murray-Darling (WGCS 2008). This also suggests that only one-third to one-fifth of the total expenditure was required to achieve a high level of environmental improvement. Given the delay, and the urgency of the situation that has evolved in the Coorong 
and Lower Lakes, it may now take up to $\$ 8.9$ billion to recover the 4000GL needed to secure the long-term health of the rivers (WGCS 2008).

\section{Conclusions}

Since the Murray-Darling Basin Agreement in 1992 a string of government initiatives have been implemented along with substantial public investment. For all the effort, there is considerable underachievement as a result of poorly informed investment decisions and persistent institutional weaknesses. The upshot of this is continued deterioration in the health of the Murray-Darling system. Furthermore, in spite of information and institutional barriers, earlier resolve to address water buy-backs could have achieved environmental improvements at substantially lower cost, even if action had been taken as recently as 2006 .

Limiting further social costs will require that future investments and decisions are transparent, based on clearly-defined targets and criteria. Improved governance to manage environmental threats, such as climate change, can be achieved by amending water-sharing arrangements between jurisdictions to align with obligations to prioritise ecological health. Better markets and policies could be designed where externalities are captured comprehensively and accurately through improved hydrological knowledge. This will also allow greater transparency in investment decisions, devoid of political motivations.

\section{References}

Ancev, T. and Vervoort, W. 2007, 'The National Plan for Water Security: Taking over the Role of a Market?', Connections: Farm, Food and Resource Issues, The University of Melbourne.

Australian Conservation Foundation (ACF) 2008, 'Toorale buy-back shows Government is listening', Feature Article 16/9/08, ACF.

Australian National Audit Office (ANAO) 2008, Regional Delivery Model for the Natural Heritage Trust and the National Action Plan for Salinity and Water Quality, Audit Report 21, Commonwealth of Australia, Canberra.

Bardon, J. 2008, Wong faces heat over water infrastructure plans, ABC News, 21 October.

Blackmore, D. 2002, 'Protecting the future', in D. Connell (ed.), Unchartered Waters, Murray Darling Basin Commission, Canberra.

Bjornlund, H. 2003, 'Farmer participation in markets for temporary and permanent water in southeastern Australia', Agricultural Water Management 63: 57-76.

Brennan, D. 2007, 'Missing markets for storage and their implications for spatial water markets', contributed paper presented at the $51^{\text {st }}$ Annual 
Conference of the Australian Agricultural and Resource Economics Society, Queenstown, New Zealand, 14-16 February 2007.

Connell, D. 2007, Water Politics in the Murray-Darling Basin, The Federation Press, Sydney.

Connell, D. and Grafton, Q. 2008, 'Planning for water security in the Murray-Darling Basin', Public Policy 3(1): 67-86.

Cooperative Research Centre for Freshwater Ecology (CRCFE) 2003, Ecological Assessment of Environmental Flow Reference Points for the River Murray system (Interim Report), Prepared by the Scientific Reference Panel for the Living Murray Initiative, Canberra.

Cooperative Research Centre for Irrigation Futures (CRCIF) 2005, Irrigation in Perspective: Irrigation in the Murray and Murrumbidgee Basins, CSIRO Land and Water.

Commonwealth Scientific and Industrial Research Organisation (CSIRO) 2007, Overview of project methods, a report to the Australian Government from the CSIRO Murray-Darling Basin Sustainable Yields Project, CSIRO.

Department of Agriculture, Fisheries and Forestry (DAFF) 2007, Phase Three of the Natural Heritage Trust, viewed April 2008, www.nrm.gov.au/funding/pubs/nht-questions.pdf.

Ferguson, S. 2008, Buying Back the River, transcript 20 October 2008.

Freebairn, J. 2005, 'Principles and issues for effective Australian water markets' in J. Bennett (ed.), The Evolution of Markets for Water, Theory and Practice in Australia, Edward Elgar, Cheltenham: 8-23.

Grafton, Q. and Hussey, K. 2007, 'Buying back the living Murray: at what price?', Australian Journal of Environmental Management 14: 74-81.

Grafton, Q. and Ward, J. 2007, 'Prices versus rationing: Marshallian surplus and mandatory water restrictions', Economics and Environment Network Working Paper, Australian National University, EEN0707.

Heaney, A., Beare, S. and Bell, R. 2000, 'Targeting reforestation for salinity management', Australian Commodities 7: 511-18.

Heaney, A., Thorpe, S., Klijn, N., Beare, S. and Want, S. 2004, 'Water charges and interregional trade in the southern Murray-Darling Basin', ABARE Conference Paper 04.14.

Letcher, R. A. and Jakeman, A. J. 2002, Experiences in an Integrated Assessment of Water Allocation Issues in the Namoi River Catchment, Technical Report Working Paper, ICAM, Australian National University. 
Murray-Darling Basin Commission (MDBC) 2006, Improvement in Accuracy of Measurements of Diversions and Return Under the Cap, Publication No. 43/06, MDBC, Canberra.

Murray-Darling Basin Commission (MDBC) 2007a, Review of Cap Implementation 2005/06, Report of the Independent Audit Group, Publication No. 12/07, Murray-Darling Basin Commission, Canberra.

2007b, Water Audit Monitoring Report 2005/06, MDBC, Canberra.

Murray-Darling Basin Commission (MDBC) 2008, The Living Murray Progress Report (Water Recovery), viewed April 2008, http://thelivingmurray.mdbc.gov.au/programs/water_recovery/progress.

Murray-Darling Basin Ministerial Council (MDBMC) 2006, Basin Salinity Management Strategy 2005-06 Annual Implementation Report, MDBC, Canberra.

National Competition Council (NCC) 2005, Assessment of Governments' Progress in Implementing the National Competition Policy and Related Reforms, NCC, Melbourne.

New South Wales Department of Environment and Climate Change (NSWDECC) 2008, Water for the Environment, viewed October 2008, http://www.environment.nsw.gov.au/environmentalwater/index.htm.

New South Wales Department of Natural Resources (NSWDNR) 2008, Water for the Environment: Environmental Rules for Rivers, viewed August 2008, http://naturalresources.nsw.gov.au/water/rivers.shtml.

Pannell, D. 2008, 'New environmental policy "Caring for our Country"' Pannell Discussions $17^{\text {th }}$ March, viewed April 2008, http://cyllene.uwa.edu.au/ dpannell/pd/pd0121.htm.

Quiggin, J. 2001, 'Environmental economics and the Murray-Darling river system', Australian Journal of Agricultural and Resource Economics 45(1): 67-94.

Quiggin, J. 2006, 'Repurchase of renewal rights: a policy option for the National Water Initiative', The Australian Journal of Agricultural and Resource Economics 50: 425-35.

Quiggin, J. 2008, 'Buying back water', John Quiggin Commentary, viewed July 2008 , http://johnquiggin.com/index.php/archives/2008/03/04/buying-back-water/.

Randall, A. 1981, 'Property entitlements and pricing policies for a maturing water economy', Australian Journal of Agricultural Economics 25(3): 195-220. 
Rolfe, J. and Mallawaarachchi, T. 2007, 'Market-based instruments to achieve sustainable land management goals relating to agricultural salinity issues in Australia', Australasian Journal of Environmental Management 14: $27-34$.

Scanlon, J. 2006, A hundred years of negotiations with no end in sight: Where is the Murray Darling Basin Initiative leading us?, MDBC, Canberra.

The Land 2008, 'Govts buy NSW cotton farm to help save Macquarie Marshes', article 7/08/08.

Vertessy, R. 2007, Advancing Water Information, presentation made at the Water Information Industry Seminar, Bureau of Meteorology, 22 November 2007, Sydney.

Wentworth Group of Concerned Scientists (WGCS) 2008, Senate Submission: Senate Inquiry into the Urgent Provision of Water to the Coorong and Lower Lakes, WGCS, Sydney.

Wong, P. 2008, 'Government water purchase secures rights to 35 billion litres for the Murray Darling', Media Release PW 69/08, Canberra. 